\title{
FAAP100 Gene
}

National Cancer Institute

\section{Source}

National Cancer Institute. FAAP100 Gene. NCI Thesaurus. Code C92472.

This gene is involved in the mediation of DNA repair by the Fanconi anemia DNA repair complex. 